\title{
IMPLEMENTASI PENGADAAN BARANG DAN JASA SECARA ELEKTRONIK DI KOTA TASIKMALAYA
}

\author{
Andi \\ STIA YPPT Tasikmalaya \\ andistiatsm@gmail.com
}

\begin{abstract}
Abstrak
Penelitian ini bertujuan untuk menggambarkan proses pengadaan barang dan jasa secara elektronik di Pemerintahan Kota Tasikmalaya. Metode yang digunakan adalah deskriptif dengan pendekatan kualitatif. Teknik pengumpulan datanya dengan wawancara dan observasi website LPSE Kota Tasikmalaya. Melalui kemudahan system yang dilakukan secara digital, proses pengadaan barang dan jasa secara elektronik yang dikerjakan dengan terbuka, tanpa gangguan atau hambatan serta bisa diawasi oleh semua stakeholder yang mempunyai rasa tanggungjawab terhadap prosesnya merupakan solusi terbaik untuk menjawab masalah-masalah pengadaan di pemerintahan Kota Tasikmalaya. Secara administrasi, implementasi pengadaan barang dan jasa secara elektronik di pemerintahan kota Tasikmalaya .sudah berjalan secara legal dn procedural serta prinsp-prinsip pengadaan barang dan jasa secara elektronik yaitu Efisien,. Efektif, Transparan, Terbuka, Bersaing, Adil atau tidak diskriminatif, Akuntabel atau bertanggungjawab sudah diimplementasikan dengan baik. Kata Kunci: Implementasi, Prinsip Pengadaan Barang dan Jasa Secara Elektronik
\end{abstract}

\begin{abstract}
The research aims to describe the process of procurement of goods and services electronically in the government of Tasikmalaya City. The method used is descriptive with a qualitative approach. Data collection techniques with interviews and observations of the website LPSE Tasikmalaya. Through the facility of the digital system, the process of procurement of goods and services electronically done openly, without interference or barriers and can be supervised by all stakeholders who have a sense of responsibility to the process is the best solution to answer the problems of procurement in the Government of Tasikmalaya. Administratively, the implementation of the procurement of goods and services electronically in the government of Tasikmalaya City has already been running legally and procedurally and the principles of procurement of goods and services electronically are efficient, effective, transparent, open, competitive, fair or not discriminatory, accountable or responsible have already been implemented well.
\end{abstract}

Keywords: implementation, principles of the electronic procurement of goods and services

\section{Pendahuluan}

Penggunaan teknologi informasi dalam bidang pemerintahan sudah mengalami perkembangan yang sangat signifikan yang dikenal dengan egovernment. E-government atau pemerintahan berbasis elektronik atau internet sidah mulai banyak dimanfaatkan unuk proses pelayanan public yang dilakukan oleh organisasi atau badan pemerintahan baik pusat maupun daerah. Tidak terkecuali sudah dilakukan oleh Pemerintahan Kota Tasikmalaya dalam bidang pengadaan barang dan jasa. Pengembangan spesifik dari e government pengadaan barang dan 
jasa adalah e-procurement, yaitu proses pengadaan barang dan jasa yang dilakukan oleh pemerintah Kota Tasikmalaya melalui jejaring internet/ website.

Proses pengadaan barang dan jasa dengan memanfaatkan internet atau teknologi digital adalah untuk mewujudkan perubahan dikarenakan banyaknya masalah yang ditimbulkan oleh proses pengadaan barang dan jasa secara manual atau konvensional, seperti adanya proses penyuapan untuk menang pelelangan, proses pelelangan yang tidak terbuka, informasi tender dan spesifikasi teknis yang hanya bisa diketahui oleh pihak pihak tertentu, persaingan yang tidak sehat diantara para penyedia bahkan ada kejanggalan perusahaan penyedia jasa yang tidak memiliki administrasi tender yang lengkap bisa ikut pelelangan dan menang. (Basrie, 2017)

Layanan Pengadaan Secara Elektronik sejak awal 2019 berada di Sekretariat Daerah Kota Tasikmalaya sebelumnya merupakan bagian dari Depkominfo, sekarang berbentuk UPTD tersendiri sehingga lebih independen dan fokus bekerja dalam memproses pengadaan barang jasa di dinas-dinas yang Sebelumnya bersifat ad hoc. Melalui UPTD ini, proyek pemerintah terkait baik itu pembangunan, renovasi, hingga pengadaan dilingkungan kerjanya dilakukan olehnya. Tugas utama dari UPTD LPSE ini adalah memfasilitasi penyelenggaraan layanan pengadaan barang dan jasa pemerintah secara elektronik. Mulai dari pelaksanaan registrasi dan verifikasi pengadaan dan lelang melalui LPSE, penyusunan program kegiatan, ketatausahaan, evaluasi dan pelaporan pengelolaan pengadaan Barang/ Jasa secara Elektronik dan lainnya. UPTD LPSE ini juga memastikan semua prosesnya berjalan secara terbuka, transparan dan akuntabel.

Dengan e-procurement, uploading (unggah) dan downloading (unduh) dokumen bisa dilakukan melalui internet. Pengumuman pemenang penyedia barang dan jasa dilakukan melalui website yang ada. Penyedia jasa dalam proses interaksi harus menunggu keputusan pemberi jasa (Pemkot Tasikmalaya). Wilayah cakupan pemberitahuannya sangat luas (bisa seluruh dunia). Kesempatan untuk berkolusi antara panitia pengadaan dan penyedia jasa bisa dikatakan kecil. . Informasi proyek dan besaran proyek pengadaan yang diselenggarakan semua tercantum dalam website

Pemanfaatan e-procurement atau pengadaan barang dan jasa secara elektronik bukan hanya untuk lembaga atau institusi pengguna dan pengembang system tersebut, tapi juga untuk provider (penyedia) barang dan jasa yang bersangkutan serta stakeholders atau para pemangku kepentingan yang bermaksud mengetahui proses pengadaan lelang barang dan jasa pada pemerintahan setempat yang bisa diakses dengan sangat terbuka dan beroperasi 24 jam. Dengan sistem digital elektronik, institusi pelaksana tender memperoleh harga penawaran yang sangat bervariasi serta proses administrasinya semakin sederhana dan tepat waktu, sedangkan untuk para penyedia (providers) barang dan jasa bisa melebarkan dan meluaskan peluang usaha mereka, mewujudkan kompetisi bisnis yang sehat, serta memberikan kesempatan bagi para pelaku bisnis untuk bergabung didalamnya dan mengefiseinsikan biaya proses administrasinya. (Muhammad et al., 2019)

Sudah rahasia umum bahwa pengadaan barang dan jasa yang dilakukan di instansi-instansi pemerintah merupakan salah satu celah untuk terjadinya penyimpangan. Mulai dari permasalahan adanya permufakatan yang tidak benar antara penyedia dengan panitia pengadaan, proses pengadaan yang kurang 
transparan dan tidak fair, dan lain sebagainya. Oleh karena itu, dalam penelitian ini peneliti akan menggambarkan sejauhmana mana implementasi prinsip-prinsip e procurement sudah berjalan dalam pengadaan barang dan jasa di Kota Tasikmalaya yatu Efisien, sesuai dengan waktu dan biaya yang dibutuhkan untuk terciptanya proses pengadaan barang dan jasa yang berkualitas.. Efektif, proses pengadaan barang dan jasa harus cocok dan tepat dengan kebutuhan dan sasaran yang telah ditetapkan dan bisa menghasilkan manfaat yang maksimal. Transparan, seluruh persyaratan dan informasi pengadaan barang dan jasa jelas dan dapat diketahui oleh semua stakeholder. Terbuka, bisa diikuti dan diakses oleh seluruh penyedia barang dan jasa yang memenuhi kriteria dan prosedur yang jelas. Bersaing, harus dilakukan secara sehat dan setara diantara para penyedia barang dan jasa dan memenuhi kriteria sehingga didapatkan harga dan barang serta jasa yang kompetitif dan tidak ada campur tangan eksekutif, legislative maupun yudikatif. Adil/tidak diskriminatif, adanya perlakuan yang sama bagi semua calon penyedia barang dan jasa tanpa kecuali. Akuntabel, proses pengadaan barang dan jasa harus dapat dipertanggungjawabkan.

\section{Penelitian Terdahulu}

Penelitian sebelumnya yang berkaitan dengan pengadaan barang secara elektroinik adalah Efektivitas E-Procurement dalam Pengadaan Barang/Jasa (Studi terhadap Penerapan E-Procurement dalam Pengadaan Barang dan Jasa di Kabupaten Bojonegoro). Penelitian ini dilakukan untuk mengetahui dan menganalisa seberapa besar pencapaian tujuan dari penerapan e-procurement barang dan jasa yang diimplementasikankan oleh Kabupaten Bojonegoro. Metode Penelitiannya adalah deskriptif kualitatif. Hasil penelitiannya adalah implementasi e-procurement di Kabupaten Bojonegoro berjalan kurang efektif, dapat disimpulkan tujuannya belum tercapai dengan maksimal. Ini diindikasikan adanya kesempatan untuk "main mata". Indikasi itu bisa jadi salah satu faktor yang bisa mereduksi keefektifan penerapan eprocurement. Karena itu, untuk mengatasi adanya fenomena peluang "main mata" tersebut, dibutuhkan kontrol yang ketat dari masyarakat dan juga Lembaga Swadaya Masyarakat seperti ICW (Indonesia Corruption Watch), sehingga tujuan implementasi sistem e-procurement dapat berjalan dengan terbuka dan baik tanpa kecurigaan. (Nurchana, 2014)

\section{Tinjauan Pustaka}

Pengadaan Barang/Jasa adalah kegiatan Pengadaan Barang/Jasa oleh Kementerian/Lembaga/Perangkat Daerah yang dibiayai oleh APBN/APBD yang prosesnya sejak identifikasi kebutuhan, sampai dengan serah terima hasil pekerjaan.(Perpres No 16 Tahun 2018, n.d.)

Menurut Indrajit e-procurement diartikan sebagai sebuah proses digitalisasi tender atau lelang pengadaan barang dan jasa pemerintah berbantuan internet. (Hidayat, 2015)

Menururt Sutedi, E procurement adalah sebuah sistem lelang dalam pengadaan barang dan jasa pemerintah dengan memanfaatkan teknologi, informasi dan komunikasi berbasis internet, agar dapat berlangsung secara efektif, efisien, terbuka, dan akuntabel.(Hidayat, 2015) 
E-Procurement adalah proses pengadaan barang/jasa yang pelaksanaannya dilakukan secara elektronik yang berbasis web/internet dengan memanfaatkan fasilitas teknologi komunikasi dan informasi yang meliputi pelelangan umum, prakualifikasi dan sourcing secara elektronik dengan menggunakan modul berbasis website.(Muhammad et al., 2019)

Pengadaan secara elektronik atau E-Procurement adalah Pengadaan Barang/Jasa yang dilaksanakan dengan menggunakan teknologi informasi dan transaksi elektronik sesuai dengan ketentuan perundang-undangan.(Peraturan Presiden No 54 Tentang Pengadaan Barang dan jasa, 2010)

\section{Prinsip E-Procurement}

Dalam Pasal 5 Peraturan Presiden no 54 tahun 2010 Prinsip prinsip pengadaan barang dan jasa di lingkungan pemerintah yaitu :

1. Efisien, berarti penggunaan dana dan waktu yang terbatas untuk tercapainya kualitas maksimal pengadaan barang dan jasa yang telah ditetapkan.

2. Efektif, berarti adanya kesesuaian pengadaan barang dan jasa antara kebutuhan dengan sasaran yang sudah ditentukan serta menghasilkan kemanfaatan yang bisa dirasakan.

3. Transparan, berarti jelasnya informasi dan kriteria pengadaan barang dan jasa serta bisa diakses secara luas dan leluasa oleh penyedia barang dan jasa yang tertarik serta oleh pemangku kepentingan atau masyarakat secara umum.

4. Terbuka, berarti seluruh penyedia barang dan jasa yang memenuhi syarat dan ketentuan yang berlaku bisa mengikuti proses tender dengan prosedur yang jelas

5. Bersaing, berarti terciptanya persaingan yang sehat diantara para penyedia barang dan jasa yang sama dan terpenuhi kriterianya, sehingga didapatkan barang dan jasa yang ditawarkan secara bersaing dan tidak diintervensi oleh pihak ketiga atau kekuasaan.

6. Adil/tidak diskriminatif, berarti adanya perlakuan yang tidak diskriminatif untuk seluruh calon penyedia barang dan jasa dan tidak bermaksud memberikan keuntungan kepada pihak-pihak tertentu, dengan tetap memperhatikan kepentingan nasional.

7. Akuntabel, berarti regulasi dan kriteria pengadaan barang dan jasa dalam proses pelaksanaanya harus sesuai sehingga bisa dipertanggungjawabkan.

\section{Tujuan E-Procurement}

Menurut Peraturan Presiden Nomor 16 Tahun 2018 pengadaan barang dan jasa pemerintah secara elektronik bertujuan untuk:

a. rnenghasilkan barang/jasa yang tepat dari setiap uang yang dibelanjakan, diukur dari aspek kualitas, jumlah, waktu, biaya, lokasi, dan Penyedia;

b. meningkatkan penggunaan produk dalam negeri;

c. meningkatkan peran serta Usaha Mikro, Usaha Kecil, dan Usaha Menengah;

d. meningkatkan peran pelaku usaha nasional;

e. mendukung pelaksanaan penelitian dan pemanfaatan barang/jasa hasil penelitian;

f. meningkatkan keikutsertaan industri kreatif;

g. mendorong pemerataan ekonorni;

h. mendorong Pengadaan Berkelanjutan (Perpres No 16 Tahun 2018) 


\section{Manfaat E-Procurement}

1. Sistem pengadaan pemerintah secara elektronik (eprocurement) bisa membuat pelaksanaan pengadaan barang atau jasa dapat berjalan secara transparan, adil dan menciptakan persaingan yang sehat;

2. Mendorong pemasok atau vendor untuk berpartisipasi dalam pengadaan publik. Selain itu, masyarakat luas dapat dengan mudah memperoleh informasi tentang tender di wilayahnya;

3. E-procurement merupakan solusi untuk mencegah dan meminimalisir adanya peluang terjadinya fraud tindakan korupsi karena semua peserta pengadaan barang/jasa dapat saling mengawasi. Selain itu, peluang untuk melakukan kontak langsung antara penyedia barang atau jasa dengan panitia pengadaan menjadi semakin kecil;

4. Tercapainya mutu produk yang didapatkan sesuai spesifikasi;

5. Mereduksi tenaga sumber daya manusia dan mengubah rutinitas pembelian;

6. Prosesnya yang secara online akan membuat peningkatan kinerja dari organisasi;

7. Menghemat biaya penyelenggaraan pengadaan barang/jasa dan mengoptimalkan waktu pelaksanaan.

8. Dalam pelaksanaannya mudah untuk melakukan pertanggungjawaban keuangan.(Pengertian e-Procurement_Jenis, Manfaat, dan Prosedur Pelaksanaannya Pengadaan Barang dan Jasa, n.d.)

\section{Metode Penelitian}

Metode penelitian yang digunakan adalah penelitian kualitatif. Penelitian kualitatif dilakukan karena peneliti ingin mengeksplorasi fenomena-fenomena yang tidak dapat dikuantifikasikan yang bersifat deskriptif seperti proses suatu langkah kerja, formula suatu resep, pengertian tentang suatu konsep yang beragam, karakteristik suatu barang dan jasa, gambar-gambar, gaya-gaya, tatacara suatu budaya, model fisik suatu artefak dan lain sebagainya. (Satori \& Komariah, 2014)

Metode penelitian kualitatif didefinisikan sebagai metode penelitian ilmu social yang mengumpulkan dan menganalisa data berupa kata-kata dan pernbuatanperbuatan nabusia serta peneliti tidak berusaha menghitung atau mengkuantifikasikan data kualitatif yang telah diperoleh dan dengan demikian tidak menganalisis angka-angka.(Afrizal, 2014)

Sumber data dalam penelitian ini diperoleh dari informan yaitu Kepala LPSE dan Penyedia Barang dan Jasa. Teknik pengumpulan data yang digunakan adalah observasi lapangan dan website LPSE Kota Tasikmalaya, wawancara dan dokumentasi. Instrumen penelitian dalam penelitian ini adalah peneliti sendiri, peneliti terjun langsung ke lapangan untuk melihat proses pengadaan barang dan jasa secara elektronik serta mengamati website LPSE Kota Tasikmalaya untuk memperkuat penelitian, melakukan wawancara dengan para informan dengan memakai alat perekam handphone dan alat tulis. Teknik analisa data yang digunakan adalah deskriptif naratif yaitu Menurut Miles dan Huberman (1984) dalam (Sugiyono, 2016, hal. 246-247) mengemukakan bahwa aktivitas dalam analisis data kualitatif dilakukan secara interaktif dan berlangsung secara terus menerus sampai tuntas, sehingga datanya 
sudah jenuh. Teknik Analisis model interaktif tersebut, terdiri dari pengumpulan data (Data Collection), reduksi data (Data Reduction), penyajian data (Data Display), dan penarikan kesimpulan (Conclusion).

\section{Hasil Penelitian}

Semua penyedia barang dan jasa dari seluruh Indonesia bisa mengikuti pelelangan pengadaan barang dan jasa secara elektronik di pemerintahan Kota Tasikmalaya dengan syarat harus mendaftar dulu di LPSE dengan mendownload formulir pendafataran dan keikutsertaan di website LPSE Kota Tasikmalaya untuk diverifikasi oleh LPSE. Dengan sudah terdaftar sebagai penyedia jasa dan barang di LPSE Kota Tasikmalaya, berarti juga bahwa penyedia tersebut bisa mengikuti proses lelang pengadaan dan barang secara elektronik di wilayah Indonesai.

Peran OPD sangat penting dalam proses tahapan lelang, tidak hanya sekedar lelang tapi bagaimana proses lelang itu direncanakan dengan baik agar menghasilkan pengadaan barang dan jasa yang berkualitas dan akuntabel serta mampu mewujudkan proses lelang yang lebih profesional dan transparan sehingga tidak terjadi permasalahan dikemudian hari.

Pengadaan barang/jasa secara elektronik akan meningkatkan transparansi dan akuntabilitas, meningkatkan akses pasar dan persaingan usaha yang sehat, memperbaiki tingkat efisiensi proses pengadaan, mendukung proses monitoring dan audit dan memenuhi kebutuhan akses informasi yang real time guna mewujudkan clean and good government dalam pengadaan barang/jasa pemerintah

\section{Efisien,}

Pemgadaan barang dan jasa secara elektronik di Kota Tasikmalaya sudah dilakukan secara efisien karena proses unduh dan unggah dokumennya melalui sistem informasi,melalui internet, penggunaaan alat tulis kantor sangat sedikit sehingga bisa mengurangi biaya kantor. Pemberkasan dokumen pun tidak banyak menguras biaya yang biasanya poto kopi dokumen-dokumen menumpuk dan memenuhi ruang kantor LPSE bisa dikatakan hampir tidak ada lagi dokumen pengadaan yang menumpuk, sudah ada di database website LPSE Kota Tasikmalaya. Display website lelang pengadaan barang dan jasa beroperasi selama 24 jam sehingga para peserta yang tertarik pengadaan barang dan jasa di lingkungan pemerintahan Kota Tasikmalaya bisa mengaksesnya kapanpun dan dimanapun, tidak perlu lagi dilakukan tatap muka antara Pelelang dengan Penyedia Jasa . Tidak ada kontak sama sekali pada saat proses pelelangan, bisa dilakukan lewat WA Web atau email sehingga efisien sekali proses negosiasinya. Baru setelah tahap pemenang tender diputuskan terjadi kontak antara Pokja LPSE dengan pemenang tender itupun sebatas administrasi dokumen. untuk proses selanjutnya terjadi di OPD Kota Tasikmalaya masing-masing yang melakukan pengadaan barang dan jasa. 


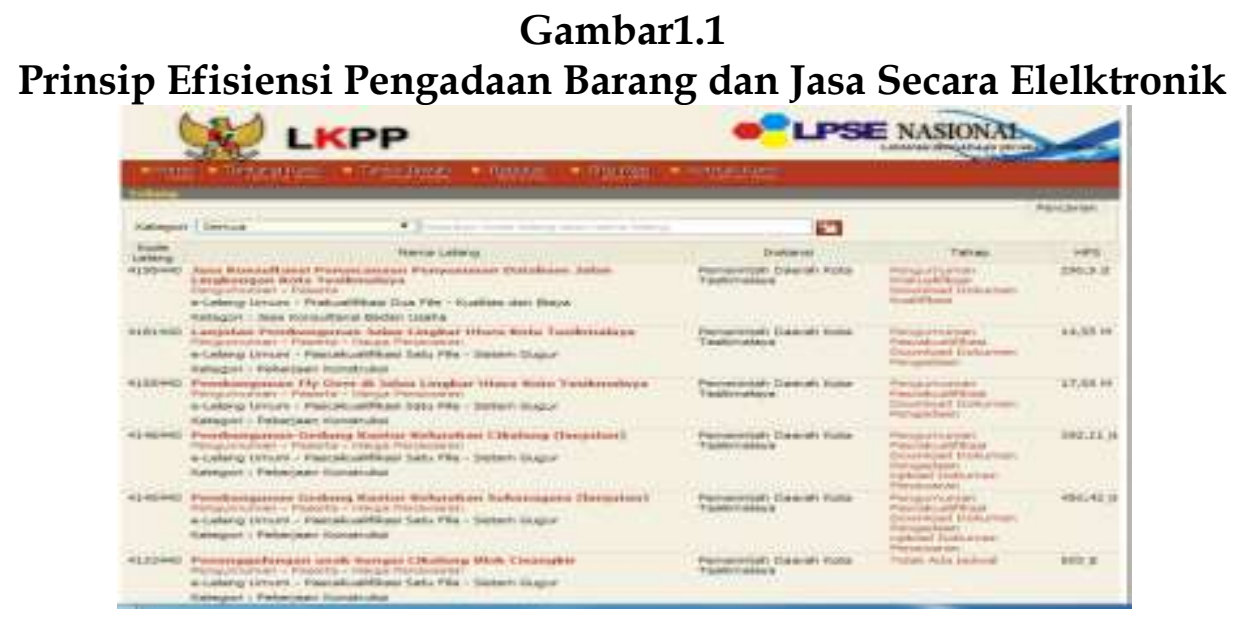

Sumber : Website LPSE Kota Tasikmalaya, 2019

\section{Efektif.}

Pengadaan barang dan jasa sudah disesuaikan dengan skala prioritas masingmasing instansi pemerintah Kota Tasikmalaya lewat kantor LPSE. Dengan pengadaan Barang dan jasa secara elektronik, peyedia barang dan jasa cepat mudah didapatkan karena jadwal Pengadaan barang dan jasa sudah tercantum di Website LPSE dan para penyedia barang dan jasa di lingkungan pemerintahan Kota Tasikmalaya tinggal mengunggah dokumen dokumen yang dipersyaratkan. Oleh karena itu, waktu prosesnya semakin cepat dan tepat waktu dan besaran Harga tender serta lamanya proses penyelenggaraan pembukaan dan penutupan pelelangan barang dan jasa sudah terjadwal dengan baik. Oleh karena itu, tujuan pengadaan barang dan jasa bisa tercapai atau efektif.

Gambar dibawah ini menggambarkan bahwa pengadaan barang dan jasa secara elektronik sudah sesuai dengan kebutuhan yang telah ditetapkan dan manfaatnya akan bisa dirasakan sebesar-besarnya setelah hasil pekerjaannya tuntas dan beres.

\section{Gambar 1.2}

\section{Prinsip Efektif Pengadaan barang Dan Jasa Secara Elelktronik}

\begin{tabular}{|c|c|c|c|}
\hline Kode Lelang & \multicolumn{3}{|l|}{4195440} \\
\hline Name Lalang & \multicolumn{3}{|c|}{$\begin{array}{l}\text { Jasa Konsultansi Perencanaan Penyusunan Database Jalan Lingkungan } \\
\text { Kota Tasikmalaya }\end{array}$} \\
\hline Keterangan & \multicolumn{3}{|c|}{ 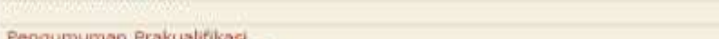 } \\
\hline Tahap Lelane Saat Ini & \multicolumn{3}{|c|}{$\begin{array}{l}\text { Pengumuman Prakuslifikasi } \\
\text { Downiload Dokumen Kualifikasi }\end{array}$} \\
\hline Instansi & \multicolumn{3}{|c|}{ Pemerintah Daerah Kota Tasikmalaya } \\
\hline Satuan Kerja & \multicolumn{3}{|c|}{ DINAS PERUMAHAN RAKYAT DAN KAWASAN PERMUKIMAN } \\
\hline Kategon & \multicolumn{3}{|c|}{ Jaso Konsultansi Badan Usaha } \\
\hline Matoden Pengadian & e-Lalang Umum & Metode Kualifikani & Prakualifikasi \\
\hline Metode Dokumen & Dua File & Metode Evaluasi & Kualitas dan Biaya \\
\hline Anggaran & \multicolumn{3}{|l|}{$2019-A P B D$} \\
\hline Nilai Pagu Paket & $\operatorname{Rp} 310,000,000,00$ & Nilai HPS Paket & Rp $290,502,300,00$ \\
\hline \multirow[t]{3}{*}{ Jenis Kontrak } & \multirow{2}{*}{\multicolumn{2}{|c|}{ Cara Pembayaran }} & Lump Sum \\
\hline & & & \\
\hline & \multicolumn{3}{|l|}{ Sumber Dana } \\
\hline Bobot Teknis & \multicolumn{3}{|c|}{ Bobot Biava } \\
\hline Lokaat Pakerjaan & \multicolumn{3}{|c|}{ kota taaikmalaya - Tauikmalaya (Kota) } \\
\hline Syarat Kualifikasi & \\
\hline Peserto Lelang & \multicolumn{3}{|l|}{7 Peserta [Detil...] } \\
\hline Dokumen Lain & \multicolumn{3}{|c|}{ Dokumen Lain } \\
\hline
\end{tabular}

Sumber : Website LPSE Kota Tasikmalaya, 2019 


\section{Transparan,}

Ketentuan mengenai persyaratan tender atau pelelangan semuanya bisa diakses lewat internet oleh siapapun,kapanpun dan dimanapun. Panitia pengadaan barang jasa dan Penyedianya serta masyarakat bisa secara terbuka dan jujur memberikan informasi-informasi tentang aturan atau persyaratan proses pengadaan. Proses transparan ini juga memberikan perhatian kepada Panitia Pengadaan Barang dan Jasa untuk bekerja secara terbuka, tidak ada kolusi, korupsi dan nepotisme karena semua stakeholder mengawasinya termasuk Komisi Pemberantasan Korupsi (KPK).

seluruh Organiasi Perangkat Daerah (OPD) yang terlibat dalam pelaksana lelang pengadaan barang dan jasa di lingkungan Pemerintah Kota Tasikmalaya wajib melaksanakan tahapan-tahapan dan mulai proses perencanaan sampai proses pengadaan yang benar. Perpres Nomor 16 Tahun 2018 tentang Pengadaan Barang Jasa, sehingga PPK, PPTK dan pihak-pihak terkait lainnya yang terlibat dalam proses pengadaan barang dan jasa harus mengacu pada aturan dan sistem yang baru dalam rangka mewujudkan proses lelang yang transparan.

Gambar dibawah ini menunjukkan informasi tender yang transparan, semua pihak penyedia barang dan jasa bisa mengetahuinya dengan mendetil sekali.

\section{Gambar 1.3}

\section{Transparansisi Pengadaan barang Dan Jasa Secara Elelktronik}

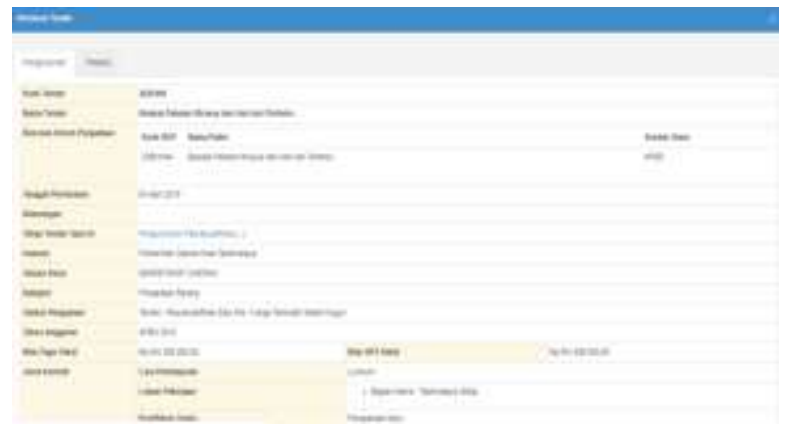

Sumber : Website LPSE Kota Tasikmalaya, 2019

\section{Terbuka,}

Untuk bisa mengikuti proses pelelangan di LPSE Kota Tasikmalaya, semua penyedia diharuskan mendaftar di website untuk mendapatkan akun login. Siapapun calon penyedia barang dan jasa yang berminat untuk mengikuti proses pelelangan bisa mendaftar dan mengunggah persyaratan-persyaratan yang disyaratkan oleh pemerintah Kota Tasikmalaya tanpa memandang berasal darimana calon penyedia tersebut. Juga, para penyedia barang dan jasa bisa bertanya sejelas-jelasnya kepada Panitia Pelelangan melalui website dan dijawab pada saat itu juga kalau pada saat jam kerja. Proses penawaran harga pengadaan ssampe proses pemenang tender bisa diikuti di websitenya berikut dengan waktu dan besaran harga tendernya. Jadi, dengan prinsip terbuka informasi proses pengadaan barang dan jasa bisa didapatkan oleh semua stakeholder tanpa kecuali. 


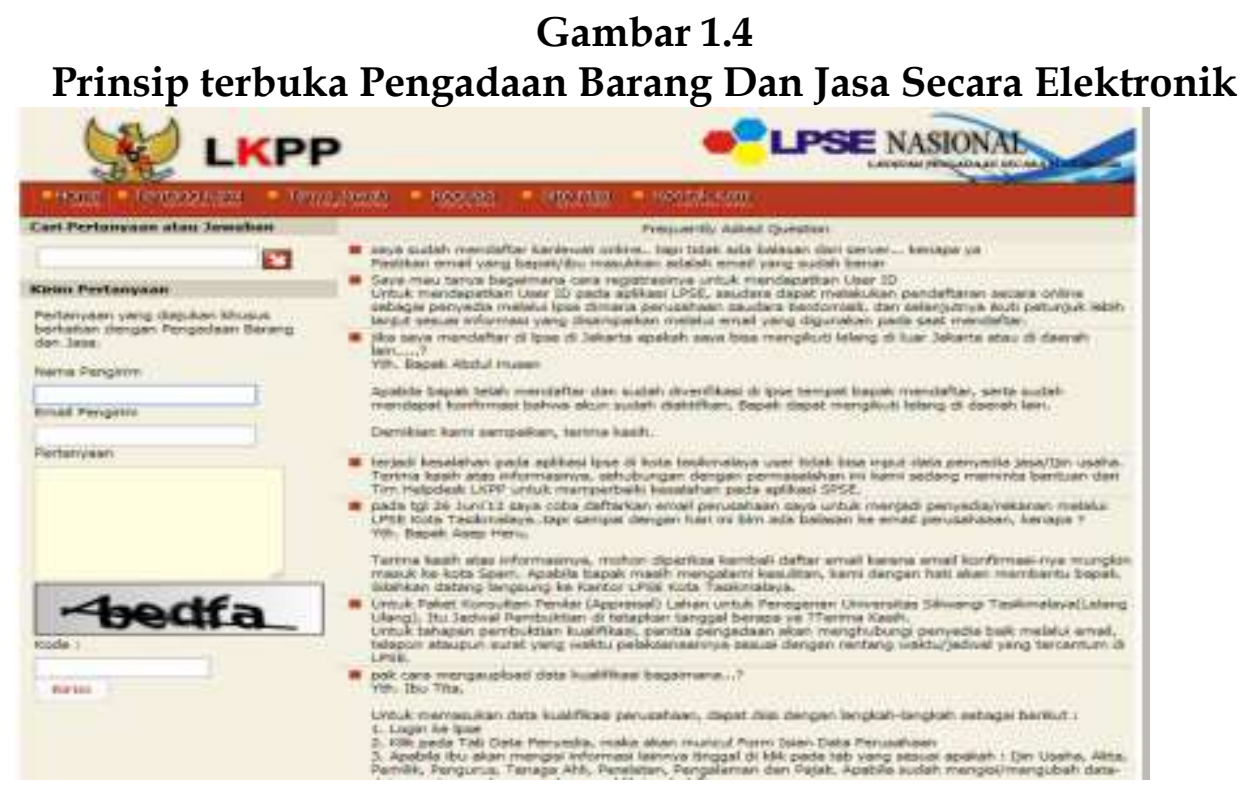

Sumber : Website LPSE Kota Tasikmalaya, 2019

\section{Bersaing,}

Setiap penyedia barang dan jasa berhak untuk ikut pelelangan dengan persyaratan sudah terdaftar di database LPSE Pemerintah Kota Tasikmalaya baik perusahaan besar maupun kecil dengan mengajukan harga penawaran yang ditawarkan. Untuk menentukan siapa pemenang tender pengadaan barang dan jasa minimal harus ada 3 peserta tender, kalau tidak memenuhinya harus diulang lagi tender tersebut.

Gambar dibawah ini menunjukkan bahwa proses pengadaan barang dan jasa secara elektronik dilakukan melalui persaingan yang sehat, pesertanya lebih dari 3 perusahaan dan secara administrasi para pesertanya sudah memenuhi persyaratan dan legal.

\section{Gambar 1.5}

Prinsip bersaing Pengadaan Barang Dan Jasa Secara Elektronik

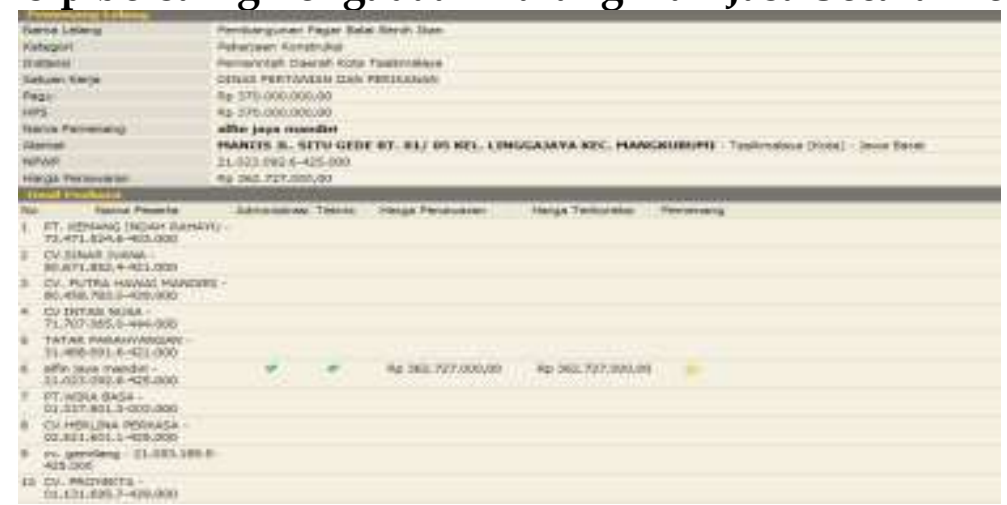

Sumber : Website LPSE Kota Tasikmalaya, 2019

\section{Adil/tidak diskriminatif,}

Dengan penggunaan website internet, semua peserta diberi hak yang sama untuk ikut pelelangan melalui unduh dan unggah dokumen lewat website. Sama 
sekali tidak ada kontak antara penyelenggara pelelangan dengan penyedia barang dan jasa. Semua interaksi proses pengadaan barag dan jasa dilakukan lewat chatting website LPSE Kota Tasikmalaya. Sehingga semua calon pemenang tender mendapat perlakuan yang sama apakah itu penyedia barang dan jasa yang besar atau Koperasi bahkan pelaku UMKM. Oleh karena itu, dengan prinsip adil atau tidak diskriminatif bisa dihindarkan konflik antar penyedia barang dan jasa karena prosesnya sudah jelas.

\section{Akuntabel atau bertanggungjawab.}

Dengan memakai sistem secara online, semua telah terkoneksi dengan petugas KPK, LKPP sehingga bisa dimonitor langsung, jadi tidak mungkin ada permainan atau kongkalikong antara pejabat pengadaan dengan rekanan penyedia barang dan jasa. Selain itu juga, para pegawai LPSE sudah mengantongi sertifikat ahli pengadaan barang dan jasa.

Gambar dibawah menunjukkan bahwa pengadaan barang dan jasa secara elektronik di pemerintahan Kota Tasikmalaya sudah sesuai dengan aturan dan ketentuan sehingga dapat dipertanggungjawabkan.

\section{Gambar 1.6}

Prinsip Akuntabel Pengadaan Barang dan Jasa Secara Elektronik

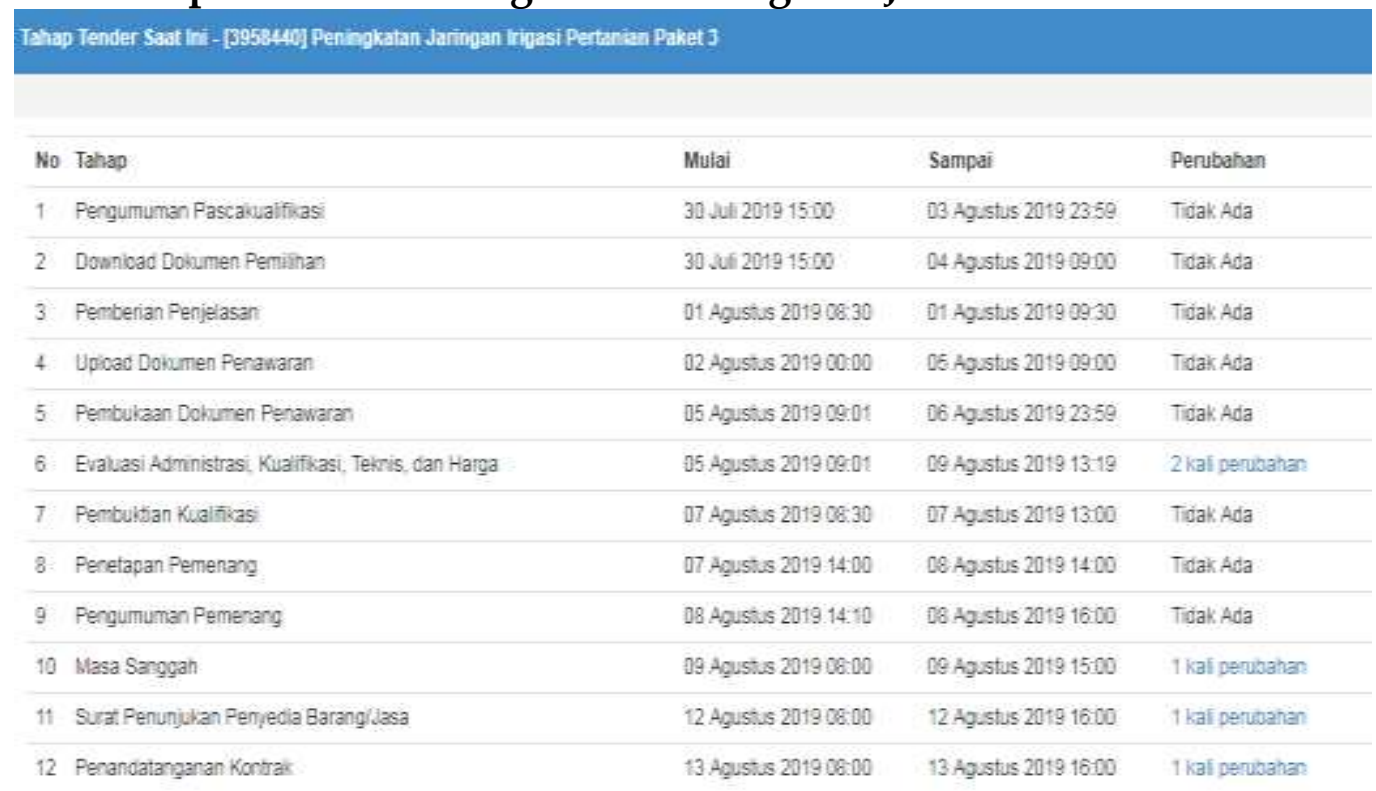

Hambatan Pelaksanaan Pengadaan Barang Secara Elektronik

1. Sumber daya manusia yang masih sedikit. Hanya ada 3 orang terlibat dalam pelaksanaan langsung pengadaan secara elektronik yaitu 1 orang administrasi, 1 orang verifikator dan 1 orang lagi kasubag.

2. Anggaran yang belum cukup. Untuk tahun 2019 saja, belum ada anggaran untuk sosialisasi pengadaan barang dan jasa secara elektronik dengan para penyedia barang dan jasa di Kota Tasikmalaya sehingga belum bisa terselenggara 


\section{Kesimpulan}

Implementasi pengadaan barang dan jasa secara elektronik di Kota Tasikmalaya dimaksudkan untuk membuat sederhana fase-fase proses pengadaan barang dan jasa serta prosesnya jadi lebih efektif secara tujuannya seperti tahap pengumuman pelelangan, tahap pencarian vendor, perbandingan harga dari masingmasing vendor, tahap pengumuman pemenang, persetujuan, pemantauan dan lebuh efisien dari segi waktu dan biaya seperti tidak dibutuhkannya dokumen dokumen tertulis pada saat proses pengadaan barang dan jasanya serta transparan bagi semua stakeholder yang terkait, bisa diakses dan dimonitor di website LPSE Kota Tasikmalaya.Jadi, proses pengadaaan barang dan jasa secara elektronik merubah pengadaan secara konvensional yang biasanya rumit, birokratis dan boros waktu. Dengan demikian, prose pengadaan barang dan jasa yang dilakukan oleh pemerintah Kota Tasikmalaya secara elektronik sudah melaksanakan prinsip-prinsip pengadaan yang baik, yaitu efektif, efisien, transparan, terbuka, bersaing, adil, serta akuntabel. 


\section{Daftar Pustaka}

Afrizal. (2014). Metode Penelitian Kualitatif. PT RajaGrafindo Persada.

Basrie, H. (2017). Analisis Pelaksanaan Pengadaan Barang/Jasa Secara Elektronik (EProcurement) Pada Pemerintah Kota Bengkulu Tahun 2015. Skripsi, 29.

Hidayat, R. (2015). PENERAPAN e-PROCUREMENT DALAM PROSES PENGADAAN BARANG DAN JASA PEMERINTAH GUNA MENDUKUNG KETAHANAN TATA PEMERINTAHAN DAERAH (Studi pada Unit Layanan Pengadaan Barang dan Jasa Pemerintah Kabupaten Penajam Paser Utara Provinsi Kalimantan Timur). Jurnal Ketahanan Nasional, 21(2), 118. https:/ / doi.org/10.22146/jkn.10155

Perpres No 16 Tahun 2018, 1.

http://www2.pom.go.id/public/hukum_perundangan/pdf/Pengamanan rokok bagi kesehatan.pdf

Muhammad, ., Djumlani, A., \& Paselle, E. (2019). Studi Tentang Pemanfaatan EProcurement Pada Dinas Pekerjaan Umum Kabupaten Kutai Timur. Jurnal Paradigma (JP), 8(1), 22. https://doi.org/10.30872/jp.v8i1.2924

Nurchana, A. R. A. (2014). Efektivitas E-Procurement Dalam Pengadaan Barang/Jasa (Studi Terhadap Penerapan E-Procurement Dalam Pengadaan Barang/Jasa Di Kabupaten Bojonegoro). Jurnal Administrasi Publik Mahasiswa Universitas Brawijaya, 2(2), 355-359.

Pengertian e-Procurement_Jenis, Manfaat, dan Prosedur Pelaksanaannya-Pengadaan Barang dan Jasa. (n.d.).

Peraturan Presiden No 54 Tentang Pengadaan Barang dan jasa, (2010).

Satori, D., \& Komariah, A. (2014). Metode Penelitian Kualitatif (6th ed.). Alfabeta.

Sugiyono. (2016). Metode Penelitian Kuantitatif, Kualitatif, dan RED. Alfabeta. 